\title{
Evaluation of stem rot disease in jute (Corchorus olitorius) germplasm caused by Macrophomina phaseolina (Tassi) Goid
}

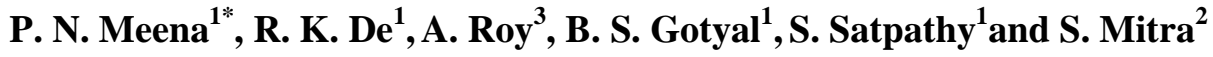 \\ ${ }^{1}$ Crop Protection Division, ICAR-Central Research Institute for Jute and Allied fibres (CRIJAF), Barrackpore, Kol- \\ kata-700120 (West Bengal), INDIA. \\ ${ }^{2}$ AINP on Jute and Allied Fibres, ICAR-Central Research Institute for Jute and Allied fibres \\ (CRIJAF),Barrackpore, Kolkata-700120 (West Bengal), INDIA. \\ ${ }^{3}$ AINP on Jute and Allied Fibres, Uttara Banga Krishi Vishwavidyalaya (UBKV), Pundibari, Coochbehar-736165 \\ (West Bengal), INDIA. \\ *Corresponding author. E-mail: Pnshera@ yahoo.co.in
}

Received: March 12, 2015; Revised received: September 2, 2015; Accepted: October 24, 2015

\begin{abstract}
This study was aimed to identify more sources of resistance in jute germplasm (Corchorus olitorius) against deadly disease of stem rot. Thirteen $C$. olitorius jute germplasm including one standard check (JRO-524) were evaluated against stem rot disease at Barrackpore, Coochbehar and Bahraich location for two consecutive years 2012-2013. Out of thirteen germplasms of jute, six germplasms OIN-853, OIN-651, OIN-154, OIN-125, OEX-27 and OIN467, with disease rating scale (1.1-5) were found moderately resistant against the stem rot disease at Barrackpore and Bahraich location. Whereas, OIN-270, OIN-932, OIN-270, OIJ-52, OIN-270, OEX-15 and OIN-853 with disease rating scale (5.1-10.0) were found moderately susceptible at all the three location. Rest of the lines were either susceptible or highly susceptible. These germplasm lines OIN-853, OIN-651, OIN-154, OIN-125, OEX-27 and OIN-467, possessed good degree of resistance against stem rot of jute and were found moderately resistant under natural epiphytotic condition at Barrackpore and Bahraich location that would be further exploited for resistance breeding programme against this deadly disease.
\end{abstract}

Keywords: Corchorus olitorius, Evaluation, Germplasm, Macrophomina phaseolina

\section{INTRODUCTION}

Jute is long, soft, shiny vegetable fibre that can be spun into coarse, strong threads is an attractive fibre for reinforcing polymers. It is produced from plants in the genus Corchorus, which has been classified in the family Tiliaceae, or more recently in Malvaceae. However, it has been reclassified within family Sparrmanniaceae. Jute is one of the most affordable natural fibre and is second important bast fibre crop next to cotton. Primarily, the jute fibre is consists of cellulose and lignin that are major part of wood fibre (Anonymous, 1990). India is the largest jute producing country and which exports considerable amount of raw jute and the diversified products. Jute fiber is used for making bags, decorative, textiles, geotextiles and its sticks are also used for fuel, door panels of automobiles and for making false ceiling boards. More than $60 \%$ of the world production of jute is in India (Anonymous, 2013). The cultivation of jute is concentrated in West Bengal, Bihar and Assam. The area and production of jute in 2012-13 is estimated to be 8.27 lakh hectares with production of 114 lakh bales (Anonymous, 1990, 2013). The total productivity of jute in India is $23.53 \mathrm{q} /$ ha with an export earnings from jute based products is to the tune of 2050 crore per annum. The jute crop and its production and productivity hampered by various diseases. The diseases are compelling crop to suffer are seedling blight, stem rot, leaf blight, root rot (Macrophomina phaseolina), anthracnose and leaf mosaic (Roy et al., 2008). Among these M. phaseolina is the causal agent of stem-rot disease in hundreds of plant species spanning a wide geographic distribution (Das et al., 2008), and is one of the most devastating pathogen to the cultivated species of jute $(C$. olitorius and C. capsularis), (Ashraf and Javaid, 2007). It attack any part of the plant at any stage of growth, right from germination to harvest resulting in decreased quantity and quality of fibre. Cloudy weather, over rainfall, high atmospheric humidity and soil temperature below $30^{\circ} \mathrm{C}$ favour infection (Rao, 1979). Although, control of disease by fungicides is an effective measure but it developed resistance mechanism against them. In recent years due to change in the climatic condition and introducing of new crops which act as an alternate host have resulted shifting of disease status in jute and allied fibre crops. Therefore, the use of host resistance could be quite appropriate to manage the disease but the jute grown in West Bengal are not yet resistant/ tolerant against the disease at least at the cultivators 
level (Mahapatra et al., 1994, Mandal et al., 2000, Kar et al., 2009 and Srivastava et al., 2011) . However, few tolerant jute cultivars/germplasm lines were identified in $C$. olitorius germ pool and these are being utilized in further breeding progaramme (De and Mandal, 2012). Keeping above in view, the present study was undertaken to identify more sources of resistance in jute germplasm and the results are reported.

\section{MATERIALS AND METHODS}

Thirteen $C$. olitorius jute germplasms OIN-853, OIN125, OIN-154, OIN-651, OIN-270, OIN-932, OEX-27, OIN-467, OEX-15, OIJ-150, OIJ-52, and OIN-110 including one standard check (JRO-524) were evaluated against stem rot disease of jute for two consecutive years 2012-2013 under natural condition at experimental plots of ICAR-Central Research Institute for Jute and Allied Fibres (CRIJAF), Barrackpore, Coochbehar and Bahraich. The jute germplasm were sown in kharif (March to August) 2012 and 2013 cropping season. Each entry was sown in a plot size of $3 \times$ $5 \mathrm{~m}^{2}$ with three replications in randomized block design (RBD) with row to row spacing of $30 \mathrm{~cm}$ and plant to plant spacing with $10 \mathrm{~cm}$. dense plants were thinned at 20-25 days after sowing. The recommended integrated package and practices were followed except use of any plant protection measure as and when required. The disease reaction was recorded on 0-5 scale as per described by (Mandal and De, 2007). Genotypes were classified in resistant (0-1\%), moderately resistant (1.1-5\%), moderately susceptible (5.1- $10 \%)$, susceptible $(10.1-20 \%)$, highly susceptible $(>20 \%)$ categories. The disease severity is based on actual damage in the individual plant that may cause loss to the plant and the number of plants observed. The individual damage of plant is based on size of lesion, position of the lesion on the stem and lesion type, whereas, the disease incidence (DI) was worked out on the basis of percentage of plant infection.

\section{RESULTS AND DISCUSSION}

It is evident from the pooled results of cropping season 2012 and 2013 at Barrackpore condition out of thirteen germplasm of jute (Table 1) revealed that four germplasm OIN-853, OIN-125, OIN-154, and OIN-651 were found moderately resistant against the stem rot disease. Whereas, OIN-270, OIN-932 were found moderately susceptible while rest of the lines (OEX27, OIN-467, OEX-15, OIJ-150, OIJ-52, JR-524 and OIN-110) were susceptible. Whereas, no lines were found highly susceptible as well as completely resistance against the disease. However, at Coochbehar location no lines were found either resistance or moderately resistance. All the lines were found moderately susceptible and susceptible. The germplasm lines OEX -27 and OIN-467 were found moderately resistance at Bahraich location, whereas OIN-270, OEX-15 and OIN-853 lines were found moderately susceptible. All the three location no germplasm lines found highly susceptible. Number of lines of jute including OIN853 , OIN-651, were reported to resistant to same disease at Assam state (De and Mandal, 2012) but other lines which were found resistant at same location were found to be susceptible at Barrackpore condition. This difference in behavior of germplasms at different locations may be due to the prevalence of different weather conditions in changing climate and genetic variability in the existing of different strains of $M$. phaseolina. The resistance and susceptibility of germplasm has been varied from germplasm to germplasm and also with in the germplasm from place to place, which might be due to the pathotypes present in particular area. The most ruling varieties JRO 524 and JRO 632 of $C$. olitorius showed differential reaction at different places and also at the same place with pathogen isolates obtained from different places (Mandal et al, 1998). When the whole set of $C$. capsularis germplasm were assessed against the pathogen, quite a good

Table 1. Reaction of jute cultivars/germplasm lines against stem rot caused by M. phaseolina.

\begin{tabular}{|c|c|c|c|}
\hline \multirow{2}{*}{$\begin{array}{l}\text { Disease rating } \\
\text { scale }(\% \text { area } \\
\text { infected })\end{array}$} & \multicolumn{3}{|c|}{ Germplasm lines (pooled data of year 2012-13) } \\
\hline & Barrackpore & Coochbehar & Bahraich \\
\hline $\mathrm{R}(0-1)$ & Nil & Nil & Nil \\
\hline MR (1.1-5) & $\begin{array}{l}\text { OIN-853, OIN-125, OIN-154 } \\
\text { and OIN-651 }\end{array}$ & Nil & OEX-27 and OIN-467, \\
\hline MS (5.1-10.0) & OIN-270 and OIN-932 & OIN-270 and OIJ-52 & $\begin{array}{l}\text { OIN-270,OEX-15 and } \\
\text { OIN-853 }\end{array}$ \\
\hline$S(10.1-20.0)$ & $\begin{array}{l}\text { OEX-27, OIN-467, OEX-15, } \\
\text { OIJ-150, OIJ-52, JRO-524 and } \\
\text { OIN-110 }\end{array}$ & $\begin{array}{l}\text { OIN-853,OIN-125,OIN- } \\
154, \text { OIN-651,OIN-932,OEX } \\
-27, \text { OIN-467, } \\
\text { OEX-15, OIJ-150, JRO-524 } \\
\text { and OIN-110 }\end{array}$ & $\begin{array}{l}\text { OIN-651, OIN-154, } \\
\text { OIN-125, OIJ-150, OIJ- } \\
52, \text { OIN-932, JRO-524 } \\
\text { and OIN-110 }\end{array}$ \\
\hline HS $(>20.0)$ & Nil & Nil & Nil \\
\hline
\end{tabular}

R: Resistant, MR: Moderately resistant, MS: Moderately susceptible, S: Susceptible, HS: Highly susceptible 
numbers of germplasm were totally free from the disease under field condition at Barrackpore as well as Budbud in West Bengal (Saha et al., 1994; Mahapatra et al., 1994). But when those C. capsularis germplasm were exposed to same pathogen at Sorbhog in Assam, most of them were severely attacked by the disease, while, at same location the six capsularis accessions, viz 'CIM 036', 'CIM 064', 'CIN 109', 'CIN 360', 'CIN 362', and 'CIN 386' were identified as resistant genotypes against the most virulent pathotype (Mandal et al. 2000). The germplasm lines 'OIN 107', 'OIN 125', 'OIN 154', 'OIN 157', 'OIN 221', 'OIN 651', 'OIN 853' and 'OIJ 084' were the olitorius accessions short listed for final confirmation as tolerant against the Macrophomina (De and Mandal 2008). (Gotyal et al. 2014) reported that, based on relative incidence of stem rot on 15 olitorius jute germplasm lines, the least incidence was seen on OIM-36 and OIJ-63 accessions whereas entry OIN-431 was found to be more resistant. Some accessions of wild species of Corchorus, like C. aestuans, C. fascicularis showed very high degree of tolerance against the disease under Barrackpore condition (Palve et al., 2003 and 2004; Sinha et al., 2003; and Srivastava et al., 2011 ). Hence, use of resistance germplasm lines and resistance wild germplasm lines are good source for further investigation of mechanism of resistance and for developing of disease resistant varieties for management of this deadly disease.

\section{Conclusion}

Stem rot of jute caused by $M$. phaseolina is major disease of jute $(C$. olitorius) in India, which results in economic losses. Presently there is no another alternative and effective method to manage this deadly disease in the field except resistant lines. Hence, it may be concluded that the germplasm lines OIN-853, OIN651, OIN-154, OIN-125, OEX-27 and OIN-467, were found moderately resistant under natural epiphytotics condition against this disease and should be further exploited for resistance breeding programme against this disease.

\section{ACKNOWLEDGEMENTS}

The authors are grateful to the Director, ICARCRIJAF, Barrackpore, Central Research Institute for Jute and Allied Fibres, Barrackpore, Kolkata, and All India Network programme (AINP) for providing the support to undertake the investigation.

\section{REFERENCES}

Anonymous, (1990). Fifty years of Research on Jute and Allied Fibres. Agriculture (1948-1997), Central Research Institute for Jute and Allied Fibres. Barrackpore

Anonymous, (2013). Annual Report. Central Research Institute for Jute and Allied Fibres, Barrackpore.

Ashraf, H. and Javaid, A. (2007). Effect of Macrophomina phaseolina on the cultivated spp. of jute. Mycopathology, 5: 81-84.

Das, I.K., Fakrudin, B. and, Arora, D.K. (2008). Reaction of different host of Macrophomina phaseolina. Microbiological Research, 163: 215-224.

De R K and Mandal R K. (2008). Identification of tossa jute (Corchorus olitorius L) germplasm tolerant to stem rot pathogen Macrophomina phaseolina (Tassi) Goid. (In) Proceedings of the International Symposium on Jute and Allied Fibres Production, Utilization and Marketing, pp 79 held during 9-12 January, Kolkata.

De, R.K. and Mandal, R.K. (2012). Identification of resistant sources of jute (Corchorus olitorius L.) against stem rot caused by Macrophomina phaseolina (Tassi) Goid. Journal of Mycopathological Research, 50: 217-222.

Gotyal B. S., Tripathi, A.N., Selvaraj, K., Ramash Babu, V., Meena, P.N. and Satpathy, S. (2014). Screening of some jute (Corchorus spp.) germplasms against stem rot caused by Macrophomina phaseolina (Tassi) Goid. J. Mycopathol. Res., 52(2): 363-365.

Kar, C.S., Kundu, A., Sarkar, D., Sinha, M.K., and Mahapatra, B.S. (2009). Genetic diversity in jute (Corchorus spp.) and its utilization: a review. Indian Journal of Agricultural Sciences, 79:587-91.

Mahapatra, A.K., Mandal, R.K., Saha, A., Sinha, M.K., Guha Roy, M.K., Kumar, D. and Gupta, D. (1994). Field evaluation of white jute (Corchorus capsularis L.) germplasm for major diseases. Information bulletin, Published by the Director, CRIJAF pp. 1-31.

Mandal, R.K. and De, R.K. (2007). Scoring technique for screening of jute germplasm lines for tolerance to stem rot pathogen Macrophomina phaseolina. JAF NEWS, pp. 5:3.

Mandal, R.K., Sarkar, S., and Saha, M.N. (2000). Field evaluation of white jute (Corchorus capsularis L.) germplasm against Macrophomina phaseolina (Tassi) Goid. Environment and Ecology, $18: 814-818$.

Mandal, R.K., Sinha, M.K., Guha Ray M.K. and Chakrabarty N.K. (1998). Studies on variation in Macrophomina phaseolina (Tassi) Goid. Causing stem rot of jute, Environment and Ecology, 16 : 424-426.

Palve, S.M., Sinha, M.K and Mandal, R.K. (2003). Preliminary evaluation of wild species of jute (Corchorus spp.). Plant Genetics Resource Newsletter No. 134: 10-12.

Palve, S.M., Sinha, M.K and Mandal, R.K. (2004). Source of stem rot Macrophomina phaseolina (Tassi) Goid. Resistance in wild species of jute. Trop. Agric. (Trinidad) 81: 23 $-27$.

Rao, P.V. (1979). Analysis of growth environmental relationship in jute (Corchorus olitorius L.). Agric. Met.16-17.

Roy, A., De, R.K. and Ghosh, S. K. (2008). Diseases of bast fibre crops and their management in jute and allied fibres, pp.327. In: Karmakar, P. G., Hazara, S. K., Subramanian T. R.,Mandal, R. K., Sinha, M. K. and Sen, H. S. (Eds.). Updates Production Technology, Central Research Institute for Jute and Allied Fibres, Barrackpore, West Bengal, India.

Saha, A., Mandal, R.K., Mahapatara, A.K., Sinha, M.K., Guha Roy M.K., Gupta, D and Kumar, D. (1994). Field evaluation of tossa jute (Corchorus olitorius L.) germplasm for major diseases. Information bulletin, Published by the Director, CRIJAF pp. 1-54.

Sinha, M.K., Mandal, R.K and Palve, S.M. (2003). Preliminary evaluation of wild species of jute (Corchorus spp.). Plant Genetics Resource Newsletter No. 134: 10-12.

Srivastava, R.K., Singh, R.K., Singh, R.B., and Maurya, K.L. (2011). Screening for tolerant capsularis jute (Corchorus capsularis L.) germplasm against major diseases. Indian Phytopathology, 64:199-200. 